\title{
Exploring the Structural Conditions Shaping Business-to-Consumer Electronic Commerce
}

\author{
Jason Cohen \\ University of the Witwatersrand \\ jason.cohen@wits.ac.za
}

\begin{abstract}
This study investigated fifteen structural factors influencing B2C e-commerce penetration across country contexts. Data collected from secondary sources on a sample of 20 countries showed that $e$ commerce penetration depends on a country's network readiness, institutional structures such as ICT laws, supply side labour skills, credit card penetration, per capita GDP and proportion of citizens online. Factors related to a country's transportation infrastructure, its capacity for technological achievement and its degree of economic freedom are also of significance. The index of structural factors collectively accounts for approximately $76 \%$ of the observed variance in $e$ commerce penetration measured as the ratio of online shoppers to total internet users, and $80 \%$ of the observed variance in e-commerce penetration measured as share of total retail sales. The index provides a basis for ongoing analysis of e-commerce and its potential for growth. Results also have important policy implications.
\end{abstract}

\section{Introduction}

Business-to-consumer e-commerce (hereafter ecommerce) is broadly defined as the buying and selling of products and services through electronic networks, along with the associated delivery of physical or digital product and the provision of after-sale service. Ecommerce is one of the main pillars of the digitalisation of economic activity. Some estimates suggest retail e-commerce sales will reach over US\$6.5 trillion by 2023 , having exceeded US $\$ 3.5$ trillion in $2019^{1}$. Global growth has been high with CAGR at $21.5 \%$ over the past 5 years, and predicted to average $8.9 \%$ over $2019-2023^{2}$. Post covid-19 estimates may be

\footnotetext{
${ }^{1}$ https://www.statista.com/statistics/379046/worldwide-retail-ecommerce-sales/

${ }^{2}$ https://www.statista.com/statistics/220177/b2c-e-commerce-salescagr-forecast-for-selected-countries/
}

higher. There are an estimated 2 billion online shoppers distributed across the globe by early 2020 . China followed by the US represent the largest ecommerce markets. Three of the top 5 e-commerce markets are in Asia Pacific, but Africa accounts for only $4 \%$ of total e-commerce, while the top 5 account for over $80 \%$ of global e-commerce ${ }^{3}$. In Germany ecommerce already accounts for $15 \%$ of retail sales, but in countries such as in Italy e-commerce sales are only around $4 \%$ of retail ${ }^{4}$. Thus despite its overall growth, the diffusion and penetration of e-commerce remains an uneven process among countries [1].

E-commerce is expected to have a strong development enhancing effect on economies [2], promising both social and economic benefits [3]. For example, e-Commerce can lead to net employment gains, wage and labour productivity growth $[4,5,6]$. Many countries are also optimistic about e-commerce boosting post covid-19 economic recovery. At the firm level, e-commerce has promoted the emergence of new business models as firms seek new ways to create value and source revenue [7]. E-commerce allows for market expansion, and increased sales through access to new domestic and global markets and distribution channels [8]. At the individual level, e-commerce has the potential to enhance consumer surplus [9]. It eliminates traditional space and time constraints, reduces search and transaction costs, and provides greater access to products and services with lower prices, more choice and convenience $[10,11]$.

Given these potential benefits, why is the penetration of e-commerce an uneven process, more sluggish in some countries than others? Some have argued that it is not simply "a matter of time" before lagging countries catch up [12]. The realisation of benefits from e-commerce may be constrained by the structural conditions of a country, i.e. whether a country has the necessary technical infrastructure, payment systems, skilled labour and legal structures

\footnotetext{
${ }^{3}$ https://www.emarketer.com/content/global-ecommerce-2019

${ }^{4}$ https://www.retailresearch.org/online-retail.html
} 
required for virtual trade [13]. E-commerce growth may thus not be sustainable in all contexts, and may not be able to contribute in the manner expected to post covid-19 recovery.

Despite early calls [1, 14] to explain the global diffusion process of e-commerce through consideration of structural conditions, the cross-country examination of e-commerce remains limited. Identifying the structural factors that explain uneven e-commerce penetration across countries and give insight into future prospects requires ongoing research attention.

The aim of this study is to investigate various structural factors that shape the potential for ecommerce across countries. We consider structural conditions related to wealth and income distribution, technical and physical infrastructure, financial systems, human capital, legal structures and the demographics of the market. The work has implications for national policy aimed at growing and sustaining e-commerce post covid-19, and for individual firms needing to develop effective e-commerce strategies aligned to their context.

\section{Related work}

Mansell [15] provided early insights into the role of structural factors by arguing that countries are in different states of readiness for e-commerce. Network access, institutional structures for promotion of trust, and developments in IT skills and capabilities were discussed as essential for improving the capacity of countries to absorb new technologies and e-commerce.

Markus and Soh [14] were however one of the first to more formally recognise the importance of structural factors in the study of e-commerce. Their conceptual work gave early insights into the structural conditions relevant to e-commerce activity. These included payment system infrastructure, legal frameworks, national policies, education, IT penetration, and logistics, among others.

Chen and Ning [16] discuss five sets of factors that determine the conditions for a successful e-commerce industry and applied these to China. They include factor conditions (e.g. telecoms and data networks, and payment systems), demand conditions in the consumer market (e.g. culture and costs of Internet access), supporting industries (such as software, finance and hitechnology infrastructure companies), and relevant legal systems. They also emphasise the role of crossindustry institutions, such as venture capital firms.

Gibbs et al. [17] presented one of the more comprehensive frameworks for thinking about the global and national factors that enable and constrain growth of e-commerce. They argued that the effects of global environment factors are mediated by national environment and national policy [17]. The position of countries in global production networks, trade liberalization and global competitive pressure can all be positive for e-commerce development. However, national factors may be more relevant in the $\mathrm{B} 2 \mathrm{C}$ ecommerce context and more important to e-commerce growth. These factors relate to market size, access to technology, IT labour force skills, income distribution and IT literacy, along with availability of venture capital, online payment systems and affordable network infrastructure.

Simon's [18] similarly distinguished technical from societal factors critical to success of e-commerce in developing contexts. Technical factors include network infrastructure, while social factors include institutional structures, country demographics such as education, and government promotion. Others similarly illustrate infrastructural barriers, socio-economic barriers, sociocultural barriers and lack of government policy and support as being primarily responsible for the limited success of e-commerce in developing country contexts [19]. Their work suggests that e-commerce would continue to lag behind in those countries unable to remove the barriers to widespread adoption.

Ho et al. [20] were among the first to empirically analyse factors affecting cross-national e-commerce growth. They presented a model based on endogenous and exogenous growth theory. They concluded from an analysis of 17 European countries that there are forces for e-commerce development that are internal to the economic system of a country and forces that are external, which spill over from other leading countries [20]. Internet user penetration, telecoms investment, and education were the most important internal factors. Ho et al. [21] extended this examination to 24 countries and examined e-commerce revenues normalised by GDP over the period 2001 to 2004 as a function of seven endogenous and exogenous factors and concluded that credit card penetration, secure server penetration, and international openness were the most significant factors for e-commerce revenue. Ho et al. [22] further extended their earlier work to an analysis of 42 countries. Their findings showed Internet use, relevant technological infrastructure, along with venture capital were important to growing e-commerce expenditure as a proportion of GDP.

In one of the larger empirical studies across 61 countries, Durbhakula and Kim [23] concluded that technology factors such as infrastructure were most important with government policy and human capital being other relevant factors. While in a study of 80 developing countries, Martinez and Williams [24] found the quality of institutional structures a critical underpinning for e-commerce growth. Mangiaracina et 
al. [25] considered 45 countries over the years 20012009 and found income inequality as the most significant factor influencing e-commerce expenditure per capita, followed by Internet user penetration.

Kshetri et al. [26] relied on 10 year panel data from 43 countries and, controlling for GDP per capita, found that consumer propensity to spend on store-based retailing was positive for e-commerce along with broadband. Akhter [27] examined e-commerce expenditure in 43 countries and showed per capita ecommerce expenditure was largely influenced by telecommunications investment and gross national income per capita. Interestingly, their analysis differed from prior work by suggesting factors such as Internet penetration and credit card penetration were not significant.

It is evident that a clear conclusion has not been reached on the relative importance of different structural factors to e-commerce outcomes. Many studies are conceptual but the few empirical studies examine different factors and have reached different conclusions. For example, while Ho et al. [21] conclude that availability of financial systems and therefore credit card penetration were highly important for e-commerce growth, others could not find a link [27]. While some found technical factors like infrastructure most important (e.g. [20, 23]), others conclude that institutional structures were most relevant (e.g. [24]), while still others point to the salience of socio-economic phenomena [25] and consumer behaviours [26]. In addition, most prior empirical studies considered e-commerce expenditure normalised by GDP, rather than as a proportion of retail. The salience of the structural factors may differ for different measures of e-commerce penetration.

\section{Research variables}

\subsection{E-Commerce penetration}

For our study, we select two measures of ecommerce penetration, namely e-commerce sales as a percentage of retail sales and the ratio of online shoppers to Internet users.

E-commerce as a percentage of total retail sales: This measure compares a country's e-commerce sales to its total retail sales. The measure is often reported in the policy and trade literatures as a measure of ecommerce development, and because it is a normalised measure it allows for easy cross-country comparison.

Ratio of online shoppers to Internet users: UNCTAD [28] show that Internet access does not automatically translate into successful e-commerce and that despite increasing rates of access, developing countries still lag behind in the percentage of consumers purchasing or ordering goods or services online. In addition, cultural resistance to online shopping has been identified as a constraint to ecommerce development in past work (e.g. [20]). This is often attributed to a lack of consumer trust in Internet technologies, online merchants and institutional structures [29]. This ratio therefore also proxies for consumer acceptance of e-commerce.

\subsection{Structural conditions}

Our choice of structural factors was informed by the previous review of related literature. We consider structural conditions as the physical, social and economic arrangements shaping e-commerce penetration and influencing how both individuals and organisations use the Internet [14].

Wealth (GDP per capita): GDP per capita is an endogenous driver of growth for e-commerce [20]. Financial resources allow for a greater extent of new product and service development, introduction of new business models and new technology development and adoption.

Inequality: Opportunities to participate in ecommerce depend on, and cannot be disentangled from, pre-existing opportunities for social and economic inclusion [30]. More equal distributions of wealth are conducive to a greater proportion of a population able to participate in e-commerce through access to technology [17]. Income inequality patterns have been found to shape e-commerce sales [25].

Technological achievement: A country's technological achievement derives from investment into tangible and intangible factors, such as R\&D and human capital [31]. Countries with lower levels of technological achievement will not be at the cutting edge of using or adapting new technologies [32]. Electronic commerce is likely to be constrained by a lack of high-technology and IT production in a country, and the further a country from the latest technologies the less likely it will be to use IT to innovate with new organisational forms [33].

Trade openness: Ho et al. [21] describe trade openness as an exogenous driver of e-commerce growth as it promotes national-level knowledge spillovers for technology adoption among countries. Countries more integrated into the global economy also have greater access to IT and other advanced digital technologies that are important to e-commerce growth [34].

Economic freedom: Regulatory or trade restrictions introduce barriers for e-commerce growth by making the country a more costly and less attractive location for production and private investment. Higher required 
levels of investment for start-ups will have a suppressing effect on e-commerce growth while ease of setting up an e-commerce business will have an enhancing effect [26].

Institutional structures: Institutional trust is necessary for e-commerce adoption [29]. Institutional structures through laws and regulations must ensure legally binding contracts, eliminate opportunistic behaviours and provide for dispute settlement in order for e-commerce activity to be successful [24]. Weak institutional structures undermine efforts to grow ecommerce, and introduce consumer uncertainties [27].

Availability of venture capital: An e-commerce setup is capital intensive [35], and funding for startups is needed to enable e-commerce growth [17, 36]. Availability of funds also has indirect effects on ecommerce growth by increasing adoption of technology among sellers [22]. Availability of venture capital has therefore been included in various research and consulting company indices of e-commerce development (e.g. [37]).

Credit card penetration: Online transactions require an appropriate payment infrastructure. Payment activity is an essential step in the process of online transaction-making [20]. E-commerce development will lag in those contexts without the means to facilitate online transactions [14].

Network readiness: The success of e-commerce depends on the availability of advanced ICT infrastructure, especially high-speed communication networks [17, 38]. ICT infrastructure determines interalia the reliability of access, frequency with which access is possible, the network speeds that consumers can expect and the pricing at which it might be available [18, 39]. Countries with better telecoms infrastructure make it easier for consumers to access and use the Internet to search for products and undertake purchase transactions [27].

Transportation infrastructure: While e-commerce has allowed for the digitisation of certain products and services, e.g. the delivery of software, videos or ebooks, most goods traded require physical delivery. Ecommerce requires an appropriate distribution network to enable the delivery of physical product. Often termed the 'last mile' challenge in e-commerce [40]. Therefore, in addition to an information infrastructure, the availability of a reliable and cost effective transportation infrastructure is considered essential to e-commerce success [38].

Labour skills: In addition to infrastructure, human capital skills are also frequently considered prerequisite for e-commerce growth. Countries that lack a skill labour pool to exploit e-commerce opportunities will be less capable of building ecommere service [19]. Skills are necessary to create new e-commerce platforms and business models, and to operate them sustainably. Translation of technology's potential into delivery of new products and services will be greater in countries with higher skill levels [15].

Ratio of Internet users to total population: The number of people online represents the potential market size and demand for e-commerce activity [22]. More individuals are likely to have online access in countries with better network infrastructure and greater levels of affordability. Number of individuals online is a dimension of e-commerce readiness index [38].

Educational attainment: High levels of education and human capital development drive computer adoption within countries [41], and act as a key input to innovation and technological progress and economic growth [42]. Average educational attainment at the national level should thus be important to e-commerce development influencing both the demand and supply sides for e-commerce growth [20].

Population density and urbanisation: High population density, particularly urban density, may act in two different ways on e-commerce penetration. On the one hand, urbanization promotes development of better infrastructure for e-commerce and increases the potential for new technologies to diffuse. However, urbanisation may also be associated with strong traditional retail that competes with e-commerce [17]. Urbanisation creates a legacy of efficient, convenient traditional retail channels for consumers [20], which may reduce their need or desire for the benefit of online shopping. The availability of retail stores brought about by higher density and urbanisation may act to reduce e-commerce spending due to crosschannel substitution effects and a reduction in the relative convenience of e-commerce to consumers [26].

\section{Selection of Countries}

Our sample of 20 countries is a judgement sample considered appropriate for an exploratory analysis of the structural conditions influencing e-commerce. The sample avoids over-representation of any one region and aims to ensure sufficient variation in levels of ecommerce penetration. The sample of 20 countries is presented in Table 1 along with their measures on ecommerce penetration.

The data on e-commerce as a percentage of retail was sourced from best available estimates from statista.com; e-marketer.com; China internet watch; and other publications ${ }^{5}$. Data for 2017 was used, or

\footnotetext{
${ }^{5}$ https://www.statista.com/statistics/281241/online-share-of-retailtrade-in-european-countries; https://www.statista.com/statistics/255083/online-sales-as-share-of-
} 
nearest possible estimates. E-commerce sales are typically defined to include sales of products or services ordered online, excluding travel and events, regardless of the method of payment or fulfillment. Ratio of online shoppers to Internet users was identified from UNCTAD data ${ }^{6}$. Although there is a strong relationship between these two dimensions of ecommerce penetration, i.e. e-commerce as a percentage of sales grows with more online users converting to online shoppers, not all the variation in e-commerce sales is explained by online shoppers. For example, as shown in Table 1, Germany, Denmark and UK have similar proportions of online shoppers but see quite different levels of e-commerce penetration when measured in terms of retail sales.

Table 1. Sample profile

\begin{tabular}{|c|c|c|c|}
\hline Region/Grouping & Country & $\begin{array}{c}\text { E-commerce } \\
\% \text { of retail } \\
(2017)^{\star}\end{array}$ & $\begin{array}{c}\text { Ratio } \\
\text { online } \\
\text { shoppers }\end{array}$ \\
\hline \multirow{6}{*}{ Western Europe } & UK & 17.3 & 86 \\
\hline & Germany & 15.1 & 82 \\
\hline & Italy & 3.4 & 41 \\
\hline & Denmark & 12.6 & 84 \\
\hline & France & 10.0 & 75 \\
\hline & Spain & 4.8 & 54 \\
\hline \multirow{5}{*}{ BRICS } & Brazil & 2.8 & 38 \\
\hline & Russia & 4.0 & 35 \\
\hline & India & 2.2 & 22 \\
\hline & China & 18.4 & 64 \\
\hline & $\begin{array}{l}\text { South } \\
\text { Africa }\end{array}$ & 1.4 & 14 \\
\hline \multirow{3}{*}{ Americas } & Mexico & 1.7 & 10 \\
\hline & $\begin{array}{l}\text { United } \\
\text { States }\end{array}$ & 8.9 & 80 \\
\hline & Canada & 7.5 & 75 \\
\hline \multirow{4}{*}{ Asia Pacific } & Japan & 7.4 & 57 \\
\hline & $\begin{array}{l}\text { South } \\
\text { Korea }\end{array}$ & 16.0 & 62 \\
\hline & Australia & 7.3 & 61 \\
\hline & Indonesia & 3.0 & 9 \\
\hline \multirow{2}{*}{ Africa } & Nigeria & 1.0 & 11 \\
\hline & Kenya & 1.0 & 16 \\
\hline
\end{tabular}

* or nearest estimates

\section{Measures and data sources}

We collected data from publicly available sources on the various structural factors within the sample of 20 countries. We relied on the most complete datasets available for each country, all measures were at 2017 or latest available (Table 2).

total-retail-sales-in-selected-countries/;

http://www.worldwideworx.com/onlineretail2019/;

https://www.chinainternetwatch.com/28092/retail-2018/

${ }^{6}$ https://unctad.org/en/PublicationsLibrary/tn_unctad_ict4d09_en.pdf
Table 2. Measures

\begin{tabular}{|l|l|l|}
\hline \multicolumn{1}{|c|}{$\begin{array}{c}\text { Structural } \\
\text { Factor }\end{array}$} & \multicolumn{1}{c|}{ Measure } & \multicolumn{1}{c|}{ Source $^{7}$} \\
\hline Wealth & GDP per capita in ppp & World Bank \\
\hline Inequality & Gini co-efficient & World Bank \\
\hline $\begin{array}{l}\text { Technological } \\
\text { achievement }\end{array}$ & $\begin{array}{l}\text { high-tech exports as \% of } \\
\text { total exports }\end{array}$ & World Bank \\
\hline Trade openness & Trade-to-GDP ratio & World Bank \\
\hline $\begin{array}{l}\text { Economic } \\
\text { freedom }\end{array}$ & $\begin{array}{l}\text { Business freedom and } \\
\text { trade freedom subscales }\end{array}$ & $\begin{array}{l}\text { Heritage } \\
\text { Foundation }\end{array}$ \\
\hline $\begin{array}{l}\text { Network } \\
\text { readiness }\end{array}$ & $\begin{array}{l}\text { Broadband subscribers } \\
\text { per 1000 }\end{array}$ & World Bank \\
\hline Labour skills & Current workforce skills & WEF dataset \\
\hline $\begin{array}{l}\text { Ratio of Internet } \\
\text { users to } \\
\text { population }\end{array}$ & $\begin{array}{l}\% \text { of population with } \\
\text { access }\end{array}$ & UNCTAD \\
\hline $\begin{array}{l}\text { Credit card } \\
\text { penetration }\end{array}$ & $\begin{array}{l}\% \text { of adults over 15 yrs } \\
\text { with credit card access }\end{array}$ & World Bank \\
\hline $\begin{array}{l}\text { Transportation } \\
\text { infrastructure }\end{array}$ & $\begin{array}{l}\text { Transportation } \\
\text { infrastructure index GCl }\end{array}$ & WEF dataset \\
\hline Population density & Individuals per square km & UN estimates \\
\hline Urbanisation & $\begin{array}{l}\% \text { population living in } \\
\text { urban areas }\end{array}$ & CIA World \\
Fact Book
\end{tabular}

\section{Empirical results}

Data on the various structural factors were standardized then aggregated into an index. Figure 2 illustrates the index values $(\alpha=0.91)$ for each of the 20 countries. Ten countries have positive index scores, while nine countries have negative scores. This index is then plotted against our measures of e-commerce penetration (Figure $3 a$ and $3 b$ ).

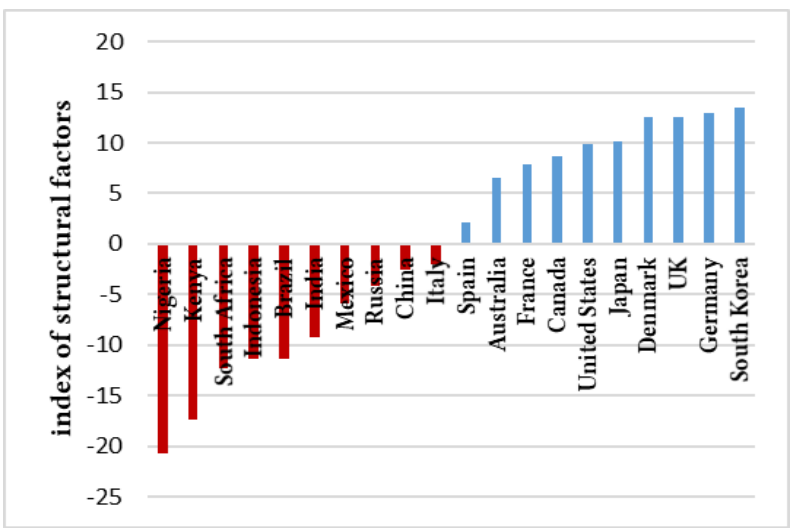

Figure 2. Country scores on index of structural factors

\footnotetext{
${ }^{7}$ https://data.worldbank.org/; https://www.heritage.org/index/; https://www.weforum.org/reports/the-global-informationtechnology-report-2016;

https://www.cia.gov/library/publications/the-world-factbook/; https://population.un.org/wpp/DataQuery/
} 


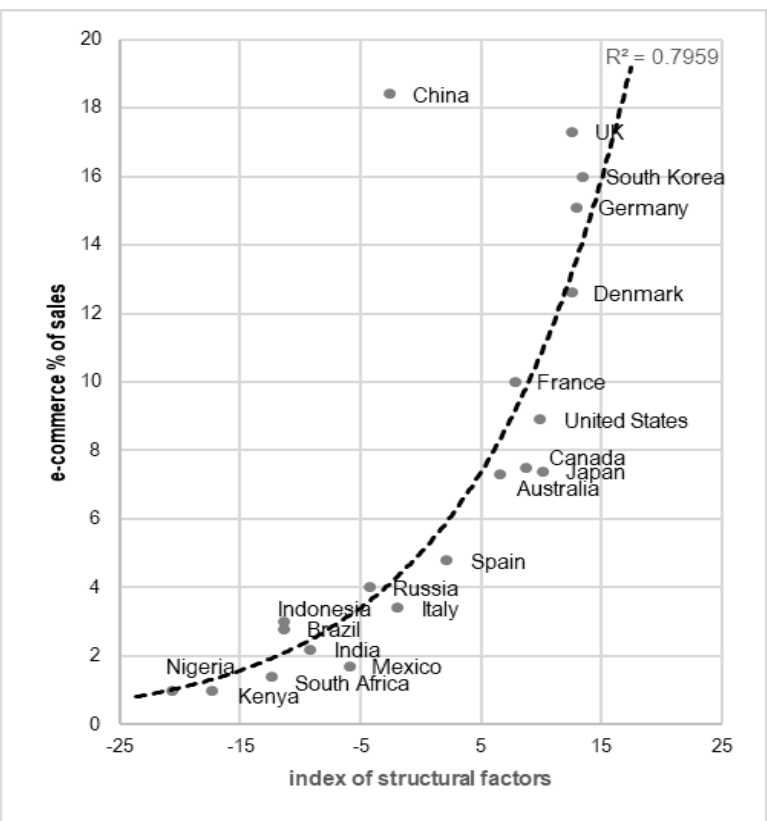

Figure 3a. Plot of index of structural factors against ecommerce Penetration (\% of retail sales)

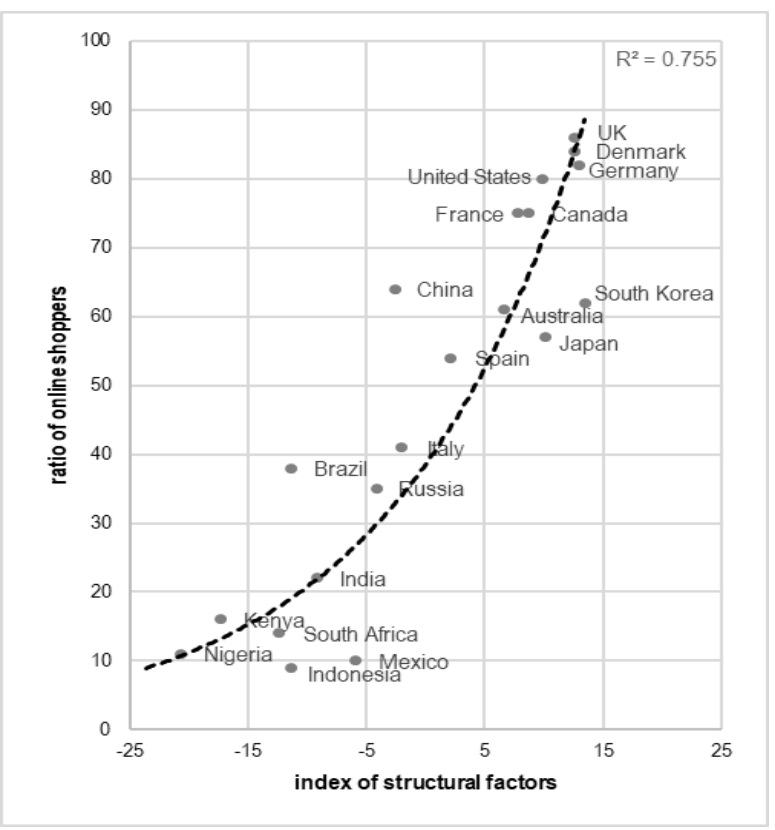

Figure $3 b$. Plot of index of structural factors against ecommerce Penetration (ratio of online buyers)

The results show that the relationship is non-linear with e-commerce penetration rising exponentially in the presence of improved structural conditions. With respect to e-commerce as a percentage of total retail sales, the $\mathrm{R}^{2}$ of the exponential function suggests the structural factors explain around $80 \%$ of the variation. China is however an outlier, and if removed from the dataset, the explanatory power of the model increases to $92.5 \%$. As shown in Figure $3 \mathrm{~b}$, the $\mathrm{R}^{2}$ of the exponential function suggests the index also explains $75.5 \%$ of the variation in e-commerce penetration measured as the ratio of online buyers to total internet users.

To further explore the relative importance of the structural factors, we used a mean split on e-commerce penetration measured as \% of sales $(\bar{x}=7.29)$ to create two groups of countries, those with higher penetration (>7.29) versus lower penetration (<7.29). We compare these two groups on each of the structural factors. Results in Table 3 show that all but three factors are statistically significant. Eight factors distinguished the high and low penetration groups at the $p<0.001$ level. These were network infrastructure, labour skills, institutional structures, GDP per capita, Internet users to total population, credit card penetration, economic freedom and technology achievement.

We similarly created two groups using a mean split on e-commerce penetration measured as the ratio of online shoppers to Internet users $(\bar{x}=48.80)$. This resulted in a high penetration group $(>48.80)$ and a low penetration group $(<48.80)$. Seven factors distinguished the high and low penetration groups at the $\mathrm{p}<0.001$ level (Table 3). These are network infrastructure, labour skills, transportation infrastructure, institutional structures, GDP per capita, Internet users to total population, and credit card penetration.

Table 3. Importance of individual structural factors

\begin{tabular}{|c|c|c|}
\hline Structural Factor & \begin{tabular}{|c|} 
E- \\
commerce \\
$\%$ of retail
\end{tabular} & $\begin{array}{c}\text { Ratio of } \\
\text { online } \\
\text { shoppers }\end{array}$ \\
\hline Network infrastructure & *** & $\star * \star *$ \\
\hline Labour skills & *** & *** \\
\hline Institutional structures & 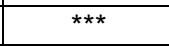 & 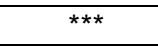 \\
\hline Wealth (GDP per capita) & 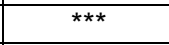 & 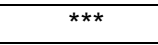 \\
\hline $\begin{array}{l}\text { Ratio of Internet users to } \\
\text { total population }\end{array}$ & $* \star *$ & $\star \star \star *$ \\
\hline Credit card penetration & 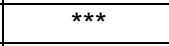 & $* \star *$ \\
\hline Economic freedom & 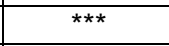 & ** \\
\hline Technology achievement & 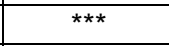 & ** \\
\hline Transportation infrastructure & ** & *** \\
\hline Inequality & ** & ** \\
\hline Urbanisation & ** & ** \\
\hline Education & * & ** \\
\hline Trade openness & $\mathrm{n} / \mathrm{s}$ & $\mathrm{n} / \mathrm{s}$ \\
\hline Population density & $\mathrm{n} / \mathrm{s}$ & $\mathrm{n} / \mathrm{s}$ \\
\hline Availability of venture capital & $\mathrm{n} / \mathrm{s}$ & $\mathrm{n} / \mathrm{s}$ \\
\hline
\end{tabular}

Figure 4 uses a radar graph to illustrate differences between the high and low e-commerce penetration groups. Inequality (Gini coefficient) was reverse scaled as higher value represents greater levels of inequality. 


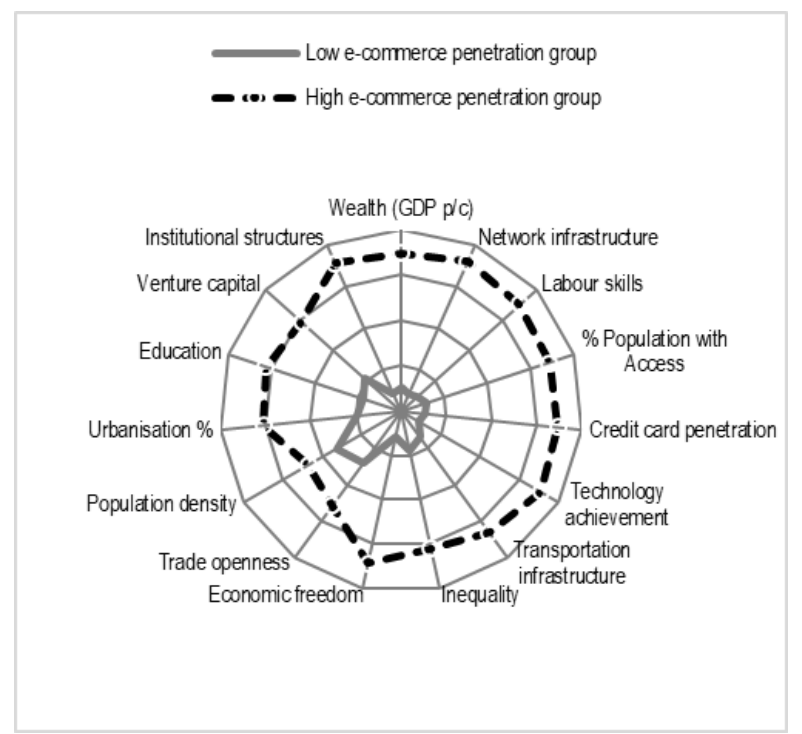

Figure 4. Plot of high versus low e-commerce penetration groups (\% of retail sales)

We further validated the importance of the structural factors by plotting the top six factors from Table 3 against e-commerce revenue per capita (Figure 5) ${ }^{8}$. This measure of e-commerce penetration was adopted by others $[20,26]$. The top six factors plotted as an exponential function explain close to $90 \%$ of the variance in e-commerce revenues per capita.

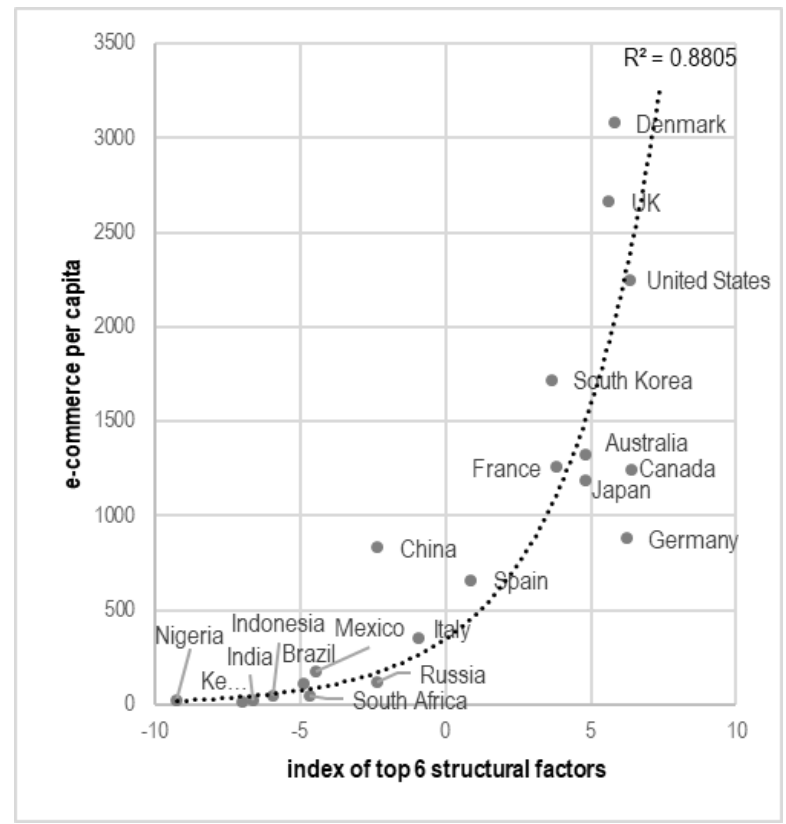

Figure 5. Plot of index of top six structural factors against ecommerce revenue per capita

\footnotetext{
${ }^{8}$ https://www.jpmorgan.com/merchant-services/insights/reports/
}

\section{Discussion}

The purpose of this study was to investigate the various structural factors that shape e-commerce penetration at the country level. This is important to understanding constraints and prospects for continued growth of e-commerce. Data on 20 countries was used to test the effects of 15 factors. Our work shows that of fifteen structural factors examined, twelve are statistically significant, with six highly significant for both measures of e-commerce penetration, and for ecommerce expenditure per capita. While past studies had not agreed on the relative salience of factors, our study adds weight to those who have concluded on infrastructure [20, 23], wealth [27], and institutional structures [24] as being of great importance. We also show the importance of labour skills. Thus, consistent with [27], we find the effects of endogenous factors more prevalent. Exogenous factors like trade-to-GDP as a measure of openness and population density were not significant for e-commerce penetration.

Early work (e.g. [17]) typically started from the premise that wealth would be a key determinant of ecommerce growth given the implications of country wealth for human capital development and infrastructure investment. Countries with greater levels of GDP per capita do, on average, observe greater levels of e-commerce penetration. However, GDP per capita does not present a complete explanation. For example, e-commerce penetration is lower in countries such as US, Australia and Canada than would be expected by GDP alone, and conversely higher in countries such as China and South Korea.

One dimension of e-commerce penetration is the ratio of online shoppers to Internet users. Interestingly, China does not have a large percentage of their population online (53.2\% in 2017) but of those online a relatively large percentage were online buyers $(64 \%)$. This can be contrasted to countries with similar levels of Internet access in 2017, but with a much lower proportion of online buyers, e.g. SA (14\%) and Brazil (38\%) and Mexico (10\%). This suggests e-commerce can penetrate more successfully with a policy focused on turning Internet users into online buyers. This effect may behind increased e-commerce demand during covid-19 national lockdowns.

Institutional structures were another highly significant factor. Martinez and Williams [24] argued that strong formal institutions are necessary to build trust in economic systems like e-commerce. Consumers must be convinced of transactional integrity. Absence of institutional trust will give rise to opportunism and have negative effects on e-commerce.

In many countries with low credit card penetration, e-commerce has not significantly developed. Ensuring 
access to online payment methods is necessary to remove transactional barriers to e-commerce. COD payment mechanisms do not easily scale and are more expensive per transaction. China has low credit card penetration. However, Chinese e-commerce platforms such as Alibaba have promoted alternative e-payment solutions, and the growth in e-commerce and its legitimacy among Chinese consumers has often been attributed to their efforts to promote e-payment solutions with guarantees for transaction security [43].

Our data also shows that countries with higher levels of e-commerce penetration have access to a more highly skilled labour market. ICT skills and education are prerequisite human capital investments required for the development of e-commerce. Ecommerce penetration requires active development of labour skills and internal capacity for technology achievement rather than relying on technology and knowledge spillovers.

Network infrastructure measured by the reach of broadband was significant. Our results support conclusions by a large number of prior studies arguing the importance of network infrastructure for ecommerce development (e.g. [17, 18, 22, 23, 26, 27]).

Past studies have placed much less emphasis on physical transportation infrastructure. Our results show quality transportation infrastructure should not be ignored for the growth of e-commerce. An infrastructure for physical fulfilment is highly important for developing countries.

This study was one of the few to explore the implications of income inequality for e-commerce. Countries with low levels of inequality such as Denmark, South Korea and France are observing better e-commerce penetration while countries with higher inequalities such as South Africa, Mexico and Brazil observe much lower e-commerce penetration. Inequalities can create disparities in consumption patterns and e-commerce is unlikely to offer a relative advantage for the purchase of basic goods and necessities by lower income consumers.

Economic freedom was measured as business and trade freedom which includes inter-alia factors of efficiency in starting a business and obtaining licenses, and the absence of regulatory barriers and trade restrictions. Economic freedom allows for growth of ecommerce by making a country more attractive for investment. Countries such as UK, South Korea and Denmark which show high levels of economic freedom exhibit higher levels of e-commerce penetration relative to countries such as India, Indonesia, Nigeria and Kenya which are scored much lower on economic freedom indicators.

Finally, urbanisation was positive for e-commerce penetration. Therefore, there is little evidence to suggest that urbanisation promotes substitution away from e-commerce but rather supports e-commerce, which may be a result of improved network and logistics infrastructures.

\section{Limitations and conclusion}

Results of this exploratory work are limited by our selection of 20 countries. We rely on e-commerce penetration data at a specific point in time and have not used lagged variables. We relied on archival data from various sources and therefore data is subject to the estimation errors and limitations of those sources. We aimed where possible to triangulate estimates but this was not always possible. Despite the growth of ecommerce, reliable statistics on e-commerce activity is not yet available for all countries.

We have left some variance unexplained and factors not considered in our model may further account for e-commerce penetration. Future work may wish to explore other structural factors or alternate operational measures. For example, our analysis focused on technology skills on the supply-side, rather than the consumer side. In many contexts, growth may be constrained by lack of digital skills to make effective use of online platforms. Furthermore, because our models cannot fully explain e-commerce penetration, additional country case studies are needed to better understand constraints and enablers at the local level.

Many of our structural factors were represented by composite indices constructed from underlying sets of factors. For example, transportation infrastructure, economic freedom, institutional structures, and labour skills. Future research may wish to disaggregate some structural conditions and explore them in greater depth.

Our paper has contributed to the sparse literature on e-commerce penetration across countries, and by including a wide range of countries we show how ecommerce penetration depends on the country's network readiness, institutional structures such as ICT laws, supply side labour skills, credit card penetration, per capita GDP, proportion of citizens online. Factors related to a country's transportation infrastructure, its capacity for technological achievement and its degree of economic freedom are also of significance.

\section{References}

[1] J.L. Gibbs, and K.L. Kraemer, "A cross-country investigation of the determinants of scope of e-commerce use: an institutional approach", Electronic Markets, 14(2), 2004, pp. 124-137. 
[2] R.D. Anvari, and D. Norouzi, "The impact of ecommerce and R\&D on economic development in some selected countries", Procedia-Social and Behavioral Sciences, 229, 2016, pp. 354-362.

[3] R. Boateng, R. Hinson, R. Heeks, and A. Molla, "E-commerce in least developing countries: Summary evidence and implications", Journal of African Business, 9(2), 2008, pp. 257-285.

[4] F. Biagi, and M. Falk, "The impact of ICT and ecommerce on employment in Europe", Journal of Policy Modeling, 39(1), 2017, pp. 1-18.

[5] E. S. Dunt, and I.R. Harper, "E-commerce and the australian economy", Economic Record, 78(242), 2002, pp. 327-342.

[6] M. Falk, and E. Hagsten, "E-commerce trends and impacts across Europe", International Journal of Production Economics, 170, 2015, pp. 357-369.

[7] C-S. Lee, "An analytical framework for evaluating e-commerce business models and strategies", Internet Research, 11(4), 2001, pp. 349-359.

[8] B.M. Fraumeni, "E-commerce: Measurement and measurement issues". American Economic Review, 91(2), 2001, pp. 318-322.

[9] E. Brynjolfsson, Y. Hu, and M.D. Smith, "Consumer surplus in the digital economy: Estimating the value of increased product variety at online booksellers". Management Science, 49(11), 2003, pp. 1580-1596.

[10] Z. Chen, and A.J. Dubinsky, "A conceptual model of perceived customer value in e-commerce: A preliminary investigation". Psychology and Marketing, 20(4), 2003, pp. 323-347.

[11] C.M. Chiu, E.T. Wang, Y.H. Fang, and H.Y. Huang, "Understanding customers' repeat purchase intentions in B2C e-commerce: the roles of utilitarian value, hedonic value and perceived risk", Information Systems Journal, 24(1), 2014, pp. 85-114.

[12] A. Molla, and R. Heeks, "Exploring ecommerce benefits for businesses in a developing country", The Information Society, 23(2), 2007, pp. 95-108.

[13] C. Maitland, (2001). "Exploring the Digital Divide: Institutional Foundations for Electronic Commerce". BLED 2001 Proceedings, 27.
[14] M.L. Markus, and C. Soh, (2002). "Structural influences on global e-commerce activity". In Strategies for eCommerce Success (pp. 17-31). IGI Global.

[15] R. Mansell, "Digital opportunities and the missing link for developing countries", Oxford Review of Economic Policy, 17(2), 2001, pp. 282295.

[16] S. Chen, and J. Ning, "Constraints on ecommerce in less developed countries: The case of China", Electronic Commerce Research, 2(1-2), 2002, pp. 31-42.

[17] J. Gibbs, K.L. Kraemer, and J. Dedrick, "Environment and policy factors shaping global ecommerce diffusion: A cross-country comparison", The Information Society, 19(1), 2003, pp. 5-18.

[18] S.J. Simon, "Critical success factors for electronic services: Challenges for developing countries", Journal of Global Information Technology Management, 7(2), 2004, pp. 31-53.

[19] J.E. Lawrence, and U.A. Tar, "Barriers to ecommerce in developing countries", Information, society and justice journal, 3(1), 2010, pp. 23-35.

[20] S.C. Ho, R.J. Kauffman, and T.P. Liang, “A growth theory perspective on B2C e-commerce growth in Europe: An exploratory study", Electronic Commerce Research and Applications, 6(3), 2007, pp. 237-259.

[21] S.C. Ho, R.J. Kauffman, and T.P. Liang, (2008, January). "A growth-theoretic empirical analysis of simultaneity in cross-national ecommerce development". In Proceedings of the 41st Annual Hawaii International Conference on System Sciences (HICSS 2008) (pp. 410-410). IEEE.

[22] S.C. Ho, R.J. Kauffman, and T.P. Liang, "Internet-based selling technology and ecommerce growth: a hybrid growth theory approach with cross-model inference", Information Technology and Management, 12(4), 2011, 409429.

[23] V.K. Durbhakula, and D.J. Kim, "E-business for nations: A study of national level ebusiness adoption factors using country characteristicsbusiness-technology-government framework", Journal of Theoretical and Applied Electronic Commerce Research, 6(3), 2011, pp. 1-12. 
[24] C.A. Martinez, and C. Williams, "National institutions, entrepreneurship and global ICT adoption: A cross-country test of competing theories", Journal of Electronic Commerce Research, 11(1), 2010, pp. 73-91.

[25] R. Mangiaracina, A. Perego, and F. Campari, "Factors influencing B2C eCommerce diffusion", International Journal of Economics and Management Engineering, 6(5), 2012, pp. 844852.

[26] N. Kshetri, R. Bebenroth, N.C. Williamson, and R.S. Sharma, "Cross-national heterogeneity in e-retail spending: a longitudinal analysis of economic, technological and political forces", Electronic Commerce Research, 2014, pp. 1-25.

[27] S. Akhter, "Infrastructural Drivers of Online Shopping: An International Perspective", International Journal of Online Marketing (IJOM), 7(3), 2017, pp. 30-41.

[28] UNCTAD (2017) "Harnessing E-Commerce for sustainable development", In Aid for trade at a glance 2017: promoting trade, inclusiveness and connectivity for sustainable development - OECD, WTO 2017.

[29] D.H. McKnight, V. Choudhury, and C. Kacmar, "Developing and validating trust measures for e-commerce: An integrative typology", Information systems research, 13(3), 2002, pp. 334-359.

[30] J. Cohen, J.M. Bancilhon, and T. Grace, "Digitally connected living and quality of life: An analysis of the Gauteng City-Region, South Africa", The Electronic Journal of Information Systems in Developing Countries, 84(1), 2018, e12010.

[31] D. Archibugi, and A. Coco, "A new indicator of technological capabilities for developed and developing countries (ArCo)", World Development, 32(4), 2004, pp. 629-654

[32] M. Desai, S. Fukuda-Parr, C. Johansson, and F. Sagasti, "Measuring the technology achievement of nations and the capacity to participate in the network age", Journal of Human Development, 3(1), 2002, pp. 95-122.

[33] J. Jalava, and M. Pohjola, "Economic growth in the new economy: Evidence from advanced economies", Information Economics and Policy, 14(2), 2002, pp. 189-210.
[34] N. Terzi, "The impact of e-commerce on international trade and employment", Procediasocial and behavioral sciences, 24, 2011, pp. 745753.

[35] M. Subramani, and E. Walden, "The impact of e-commerce announcements on the market value of firms", Information Systems Research, 12(2), 2001, pp. 135-154.

[36] P. Kalia, N. Kaur, and T. Singh, (2018). "ECommerce in India: evolution and revolution of online retail". In Mobile commerce: Concepts, methodologies, tools, and applications (pp. 736758). IGI Global.

[37] A.T. Kearney (2015). “Global Retail ECommerce Index: Global Retail E-Commerce Keeps On Clicking". Available online: https://www.kearney.com/consumerretail/article?/a/global-retail-e-commerce-keepson-clicking

[38] UNCTAD (2017). "Information Economy Report 2017". Available online: https://unctad.org/en/PublicationsLibrary/ier2017 en.pdf

[39] ITU. (2019). "State of Broadband Report 2019": Geneva: International Telecommunication Union and United Nations Educational, Scientific and Cultural Organization, 2019. Licence: CC BYNC-SA 3.0 IGO.

[40] H.L. Lee, and S. Whang, "Winning the last mile of e-commerce", MIT Sloan Management Review, 42(4), 2001, pp. 54-62.

[41] D. Comin, and B. Hobijn, "Cross-country technology adoption: making the theories face the facts", Journal of Monetary Economics, 51(1), 2004, pp. 39-83.

[42] J. Benhabib, and M.M. Spiegel, "The role of human capital in economic development evidence from aggregate cross-country data", Journal of Monetary Economics, 34(2), 1994, pp. 143-173.

[43] J. Kwak, Y. Zhang, and J. Yu "Legitimacy building and e-commerce platform development in China: The experience of Alibaba", Technological Forecasting and Social Change, 139, 2019, pp. 115-124. 